\title{
チャンバー法による植物の窒素酸化物質除去効果 \\ REMOVAL EFFECTS OF NITROGEN-OXIDES OF PLANT BY CHAMBER METHOD
}

\author{
藤 井修二*, 車 熙 運**, 宮 村 壽***, 鍵 直 樹**** \\ Shuji FUJII, Hiun CHA, Hisashi MIYAMURA \\ and Naoki KAGI
}

\begin{abstract}
The removal effect of NOx (nitrogen-oxides) is an important factor for finding the material cycle in urban environment. But there are few investigations carried out to characterize the removal efficiency of air pollutants by plants. In this paper, the removal effect of NOx by adsorbing and absorbing on plants was studied experimentally. The chamber having NOx concentration such as atmosphere environment was designed for the experiment. Plants were exposed to the environmental concentration level of $\mathrm{NO}_{\mathrm{X}}$ in the chamber designed for the experiment, and the removal effects of partitioned parts of plants were evaluated as a NOx sorption flux calculated by measurement data of decreasing trend for NOx concentration in the chamber. The correlation of $\mathrm{NO}$ s sorption velocity and $\mathrm{CO}_{2}$ absorption velocity was evaluated.
\end{abstract}

Keywords : plant sorption, air pollutant, Carbon dioxide $\left(\mathrm{CO}_{2}\right)$, Nitrogen Oxides $(\mathrm{NO}$.

植物収着、大気污染物質、二酸化炭素 $\left(\mathrm{CO}_{2}\right)$ 、窒素酸化物 ( $\left.\mathrm{NO}_{\mathrm{N}}\right)$

1. はじめに

都市域において緑化の促進が叫ばれるようになり、建築物に対し ても、壁面緑化、屋上緑化などの必要性、重要性が盛んに取り上げ られている。建物周辺の植栽には、熱·風・音·大気環境負荷低減に寄 与寸る効果が大きく、特に直射日光の遮断による外壁からの熱負荷 低減に有効であり 》、自然エネルギー利用の観点から注目されてい るが、そのような中で、建築植栽を大気污染物質除去に有効利用す ることが期待されている。

植物による、大気污染物質の除去能力については、植物自体の植物 内八の固定化 2)、植物表面への吸着、土壌中に存在寸る土中菌の持 つ污染物質分解作用 沙等、定性的な報告が行われている。これらの 要素を生かし、都市域における植物をより有効に大気污染物質除去 に活用寸るためには、まず植物の持つ大気污染物質除去の特性につ いて把握する必要がある。

植物の吸収作用による窒素酸化物除去効果については、既往の研 究において窒素酸化物吸収量を二酸化炭素吸収量より推定するモデ ル等が提案されている1。植物表面への吸着を含めた窒素酸化物除 去効果については、実際の環境よりはるかに高い濃度レベルでは測 定されているが、実際の環境濃度レベルにおけるる測定例は乏しいの が現状である。本研究では未だ環境基準を満足させるに至らない窒
素酸化物(NON)に着目し、都市域の一般大気レベルの環境下に植栽 した場合の植物による NOx 削減効果を検証することを目的として いる。また地球温暖化に大きく寄与している二酸化炭素 $\left(\mathrm{CO}_{2}\right)$ の吸収 実験を行い、 $\mathrm{NO}$ 収着フラックスと $\mathrm{CO}_{2}$ 吸収フラックスの関係式 より NOxの吸収・吸着効果を検証した。外気噮境に近い空間を有す る測定システムを考案し、污染物質濃度を植物の有無により比較す ることで季節の違いによる大気污染物質除去効果を検証した。

2. チャンバーの概要及び基本性能

植物の NOx浄化能力の測定には図 1 に示すチャンバーを用いた。

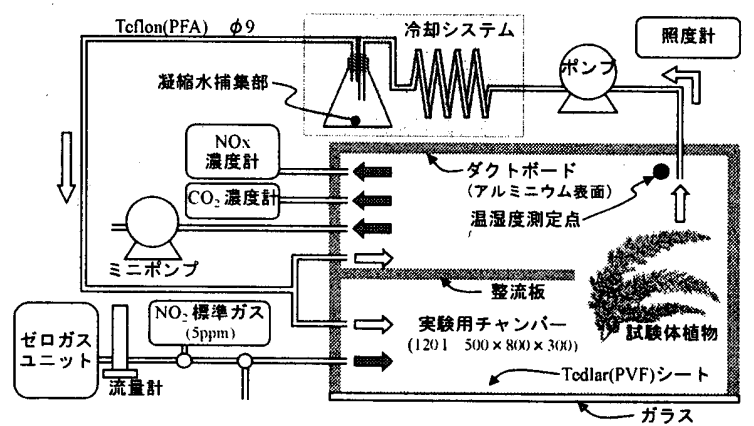

図 1 実験装置の概要

\footnotetext{
* 東京工業大学大学院理工学研究科情報環境学専攻 教授・工博

** 東京工業大学大学院理工学研究科 大学院生

*** 金沢福祉尃門学校 博士 (工学)

**** 国立保健医療科学院建築衛生部 研究員 ·博士 (工学)
}

Prof., Department of Mechanical and Environmental Informatics, Graduate School of Information Science and Engineering, Tokyo Institute of Technology, Dr. Eng. Graduate Student, Graduate School of Information Science and Engineering, Tokyo Institute of Technology

Kanazawa Welfare College, Dr. Eng.

Researcher, Dept. of Architect. Hygiene Eng. and Housing, National Institute of Public Health, Dr. Eng. 


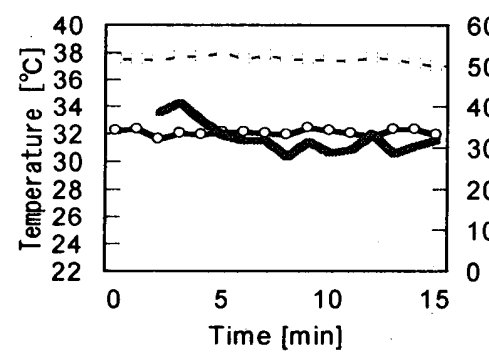

（a）冷却装置なし

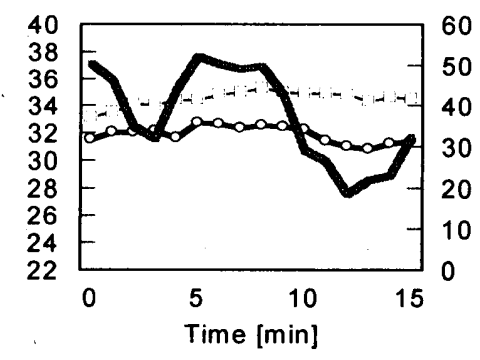

(b) ポンプのみ作動

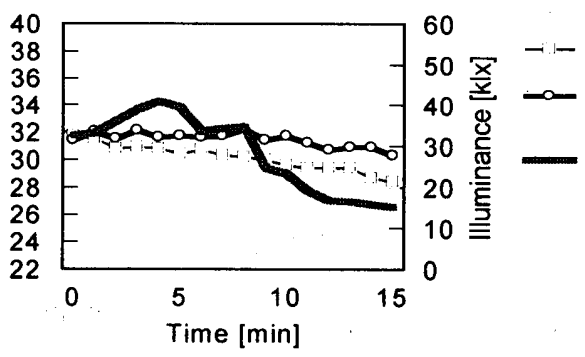

（c）冷却装置作動
内部温度 外部温度 照度

図 2 冷却装置の作動条件による温度・照度の差

実験用チャンバー（内寸が 500(W) 800(D) 300(H)mm、内部容積 $\left.0.12 \mathrm{~m}^{3}\right)$ は南面及び上面は普通板 $6 \mathrm{~mm}$ ガラス、その他の面は両表 面をアルミニウムフィルムで仕上げた $16 \mathrm{~mm}$ 厚のボードにより構 成されている。チャンバ一内部には外気流入口から流出口までの空 気のショートカットを防止する整流板 $(16(\mathrm{~W}) \sim 500(\mathrm{D}) \sim 300(\mathrm{H}) \mathrm{m})$ を 設置し、植物及び検体は整流版が終わる所からチャンバー床に置く 形になっている。また、チャンバー内部は日射や植物の蒸散作用に より高温・多湿となる為、チャンバー内空気を椧却・除湿する冷却系 （50 l/min ポンプ、冷却管、三角フラスコ）を設けた。チューブ類 は冷却系にはNOx吸着の少ない Teflon(PFA)チューブ(内径 9mm)を、 測定機器との接続部には主として Teflon(PFA)チューブ(内径 1/4イン チ)を用いている。また、試験用ガス及び外気導入装置（高濃度バッ グ）を設置した。実験で使用された測定装置としては、窒素酸化物 濃度測定に化学発光法による $\mathrm{NO}-\mathrm{NO}_{2}$ 自動分析計(日本サーモエ レクトロン(株)製 MODEL42C)を用いた。また、二酸化炭素濃度 は非分散赤外線式の一酸化炭素・炭酸ガス測定器((株)ガステック製 CMCD-10、CMCD-11)を、鉛直面照度は受光素子にシリコンフォト ダイオードを使用したデジタル照度計(東京光電(株)製 ANA-F11) をそれぞれ用いて測定を行った。

\section{1 チャンバー内部の気流及び日影}

内部気流については線香の煙及びドライアイスの煙を用いて行っ た簡単な気流の可視化実験で、整流板の効果によりサンプリング吸 い込み口と吹き出しロのショートカットが生じないことを確認した。 また、チャンバー内には日射による日影が生じないように設定した。

\section{2 チャンバー冷却装置の評価}

夏期の実験において、チャンバー内温湿度の上昇を抑制するため に冷却・除湿装置を実験装置に組み込んだ。夏期において冷却装置 使用時と停止時のチャンバー内温湿度を比較することにより冷却装 置の効果について検証した。実験条件はチャンバー内に試験体を㨉 入せず、「冷却装置を作動させない場合」「冷却装置を作動させる場 合」「ポンプでのチャンバー内空気の強制循環を行うものの泠却し ない(空回し)」の 3 条件で行った。測定はガラスを閉じてチャンバ 一を密閉してから 15 分間行い、3 条件におけるチャンバー内温度・ 照度の測定結果を図 2 に示す。これより、今回考案した泠却除湿装 置を使用することでチャンバー内部温度は外気と $5^{\circ} \mathrm{C}$ 前後の差に押 さえられることが確認された。また湿度の場合、外気湿度が平均 $42.2 \%$ に対し、冷却装置を作動させる場合のチャンバー内植物周辺 に㧍ける平均湿度は $38.8 \%$ を示した。この時、15 分間の実験におい て 7.6ml の凝縮水が捕集され、冷却系による冷却除湿効果があるこ

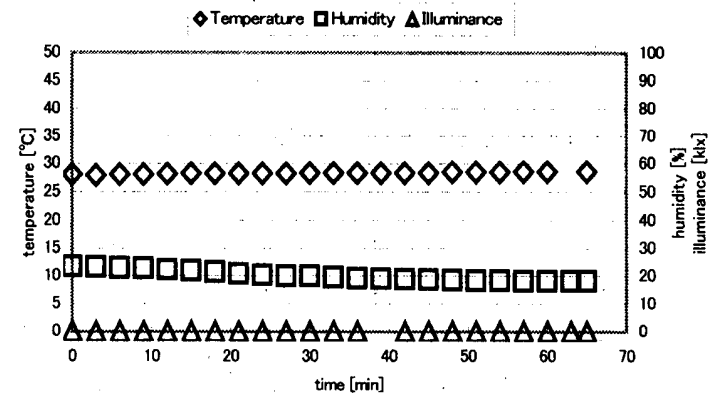

図 3 システムブランクの測定時の温湿度及び照度

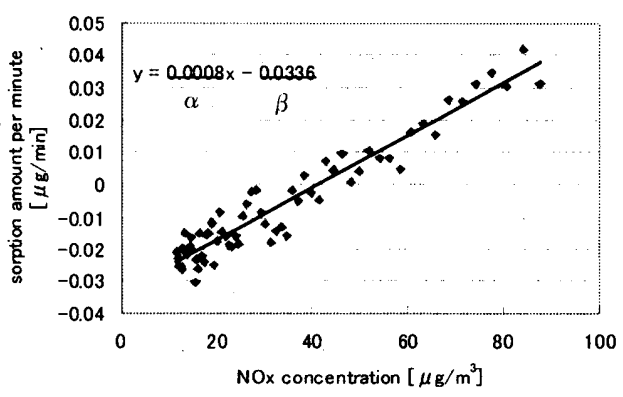

図 4 システムブランクの測定・回帰例

とが確認できる。

\section{3 測定システムの $\mathrm{N} 0$ 吸脱着特性}

チャンバー内部に何も入れない状態を測定システムのブランクと して嶩度減衰実験を行い、測定システム自体の NOx 吸脱着特性の評 価を行った。ブランクの測定時の温度、湿度、及び照度を図 3 に示 す。ブランクの測定結果における単位時間当りの NOx吸着量と NON 濃度の関倸の例を図 4 に示す。Henry 型吸着においては、式(1)〜 (3) に示す吸脱着フラックスの式として表す事ができるて。

$$
\begin{aligned}
& u_{a}=k_{a} s C \quad \text { 但し、 } \quad k_{a}=\frac{A}{\sqrt{M_{a} T}} \\
& u_{d}=N k_{d} \quad \text { 但し、 } \quad k_{d}=B e^{-\frac{\varepsilon_{d}}{R T}} \\
& u=u_{a}-u_{d}=k_{a} s C-N k_{d}
\end{aligned}
$$

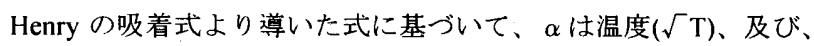
付着確率 $s$ に影響を及ぼす可能性のある絶対湿度と、 $\beta$ は温度 $(\operatorname{Exp}(-1 / \mathrm{T}))$ 、及び、表面吸着量に関係のあると思われる周辺 NO $\mathrm{N}$ 濃 度の履歴との相関を見た。絶対温度と $\alpha$ の関係(図 5)は、通常環境に 
おいて $\mathrm{T}^{-1 / 2}$ の值が殆んど変化しないために相関は見られず、本研究 に㧍ける実験の条件下では、絶対温度はあまり測定システムへの NO、吸着に影響しないことが考えられる。また、絶対湿度と $\alpha$ の相 関は図 6 に示すように絶対湿度との相関が高いことから、絶対湿度 は測定システムへの NON吸着に影響を与えるものとし、相関関係の 回帰式より $\alpha$ を絶詨湿度の関数として次(4)の式に表すこととした。 $\alpha=4 \times 10^{-5} \sigma+0.0002$

絶対温度と $\beta$ の関係を示寸図 7 には通常環境において $\operatorname{Exp}(-1 / \mathrm{t})$ の 值は殆んど変化しないために相関が見られず、本研究の実験条件下 では、絶対温度は測定システムからの NOxの脱着にあまり影響しな いことが考えられる。また、図 8 に示すようにNOX 濃度履歴と $\beta$ の 関係が高いことから、NO、濃度履歴は測定システムからの脱着に影 響を与えるものとし、相関関係の回帰式より、 $\beta$ を NOx 濃度履歴の 関数として式(5)の様に表すこととした。

$\beta=-0.0009_{\text {. }} C_{\mathrm{w}} C_{t=(0) \rightarrow 0}-0.009$

以上より本実験における測定システムの NOX吸脱着特性を、

$-M=\left\{4 \times 10^{-5} \sigma+0.0002\right\} C+\left\{-0.0009_{\text {.ive }} C_{(t=6) \rightarrow(0)}-0.009\right\}$

として表し、Mの值をチャンバーからの NON 放出量として、植栽 によるNOx収着を評価する際の理論值の算出に用いることとした。 2.4 凝縮水中のイオンについて

冷却システムに捕集される凝縮水中に NOX が溶解されることが 考えられ、凝縮水中のイオンの検討を行った。気中の NOxが凝縮水 中に溶解することにより亜硝酸イオン $\left(\mathrm{NO}_{2}-\right)$ 及び硝酸イオン $\left(\mathrm{NO}_{3}-\right)$ の陰イオンとなる。インピンジャーを用いて NO 及び $\mathrm{NO}_{2}$ ガスを 純水にバブリングして捕集した後、捕集液中の陰イオンについてイ オンクロマトグラフを用いて分析を行った。捕集時の設定条件を表 1 に示す。気中の硝酸塩の溶解を防ぐために粒子を、光照射による 測定システムからの分解を防ぐために光をそれぞれ排除した。捕集 液の分析結果を表 2 に示す。 $\mathrm{NO}$ 及び NO2 ガスを捕集した純水から 両イオン共に検出されている。NO2-についてはゼロガスを捕集した 際にはいずれの条件からも検出されていない。また特に $\mathrm{NO}_{2}$ 標準 ガスを捕集した際に高濃度で検出されていることから、 $\mathrm{NO}_{2}$ が溶解 し $\mathrm{NO}_{2}$ となることがいえる。 $\mathrm{NO}_{3}$ とについてはゼロガスを捕集した 純水からも検出されていることから、気中の NOx 由来以外にも考え られる。粒子の影響のない条件下においても同様に検出されている ことから粒子に由来する可能性は低いといえる。更に光の影響のな い条件下においては検出されていないことより、NO3-が発生する原 因として、配管の材料中の紫外線吸収剂に含まれる窒素分が、光の 影響で配管中から分解寸ることが考えられる。結果より、本測定シ ステムに拈いては NO3-は気中の NOx 以外に発生源が考えられるこ とから、NO3-は考慮せず、NO2-のみを気中の NOxが溶解したもの として取り扱った。

\section{3. チャンバーによる $\mathrm{CO}_{2}$ 及び NOx 除去量の測定}

\section{1 実験対象体及び測定期間}

実験対象体を表 3 に示す。壁面緑化植物としての利用が期待され ているハイネズ (Juniperus conferta parl、木本類) おうよひ比較対 象植物としてへデラ (Ivy、ツル植物) の 2 種類の試験体植物を用い た。各植物の葉面積は、各期間にデジタルカメラで撮影し、林学や 植物 (森林) 生態学分野で使用されている LIA32 の葉面積計測機能

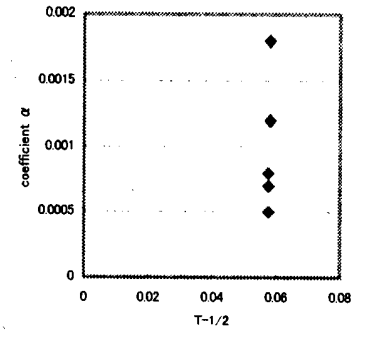

図 5 絶対温度と $\alpha$ の相関

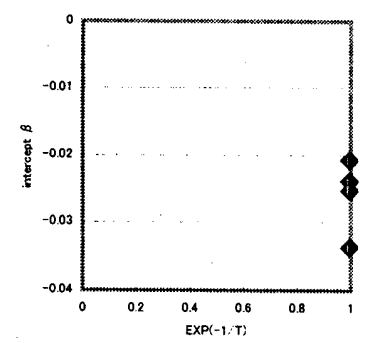

図 7 絶対温度と $\beta$ の相関

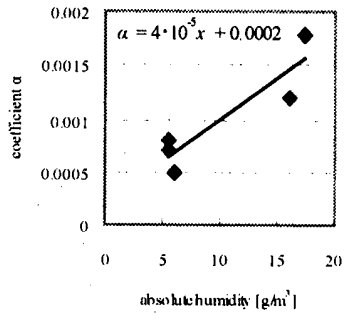

図 6 絶対湿度と $\alpha$ の相関

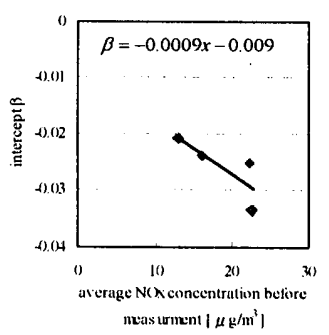

図 8 濃度履歷と $\beta$ の相関
表 1 凝縮水中イオン検討時の実験条件

\begin{tabular}{|c|c|c|c|c|}
\hline \multirow{3}{*}{ 捕集対象ガス } & \multicolumn{2}{|c|}{ ゼロガス $(\mathrm{NOx}=0 \mathrm{ppb})$} & 捕集液 & 純水 $10 \mathrm{ml}$ \\
\hline & \multicolumn{2}{|c|}{$\mathrm{NO}$ 標準ガス(NO=5ppm) } & 捕集時間 & 1 hour \\
\hline & \multicolumn{2}{|c|}{$\mathrm{NO}_{2}$ 標準ガス $\left(\mathrm{NO}_{2}=5 \mathrm{ppm}\right)$} & 捕集流量 & $2 \mathrm{l} / \mathrm{min}$ \\
\hline \multirow{3}{*}{ 排除する影響 } & なし & \multicolumn{3}{|c|}{ 捕集対象ガスを直接捕集液にバブリング } \\
\hline & 粒子 & \multicolumn{3}{|c|}{$\begin{array}{l}\text { 空気の清浄な人工気象室内において、捕集対象 } \\
\text { ガスをメンブレンフィルターを通すことにより } \\
\text { ガス中の粒子を排除した後、捕集液にバブリン } \\
\text { グ }\end{array}$} \\
\hline & $\begin{array}{l}\text { 粒子 } \\
\text { - 光 }\end{array}$ & \multicolumn{3}{|c|}{$\begin{array}{l}\text { 条件'粒子’と同様の環境において、更に測定シス } \\
\text { デムの配管類をアルミにより被覆寸るこことで遮 } \\
\text { 光し、捕集液にバブリング }\end{array}$} \\
\hline
\end{tabular}

表 $2 \mathrm{NOx}$ 捕集液の分析結果

\begin{tabular}{c|c|c|c}
\hline \multirow{2}{*}{ 曝露したガス } & 排除した影響 & $\begin{array}{c}\mathrm{NO}_{2} \\
{[\mathrm{mg} / \mathrm{l}]}\end{array}$ & $\begin{array}{c}\mathrm{NO}: 3 \\
{[\mathrm{mg} / \mathrm{l}]}\end{array}$ \\
\hline \multirow{3}{*}{ ゼロガス (0ppm) } & なし & Not found & 1.34 \\
\cline { 2 - 4 } & 粒子 & Not found & 1.98 \\
\cline { 2 - 4 } & 粒子・光 & Not found & Not found \\
\hline \multirow{2}{*}{ NO 標準ガス (5ppm) } & なし & 0.00943 & 2.54 \\
\cline { 2 - 4 } & 粒子 & Not found & 1.87 \\
\cline { 2 - 4 } & 粒子・光 & Not found & 0.984 \\
\hline \multirow{2}{*}{$\mathrm{NO}_{2}$ 標準ガス (5ppm) } & なし & 0.858 & 1.94 \\
\hline
\end{tabular}

表 3 実験対象項目

\begin{tabular}{c|c|c}
\hline 植栽 / 材料 & $\mathrm{CO}_{2}$ & $\mathrm{NOx}$ \\
\hline ハイネズ(木本類 $)$ & 3検体 $(\mathrm{A}, \mathrm{B}, \mathrm{C})$ & 2検体 $(\mathrm{A}, \mathrm{B})$ \\
\hline ヘデラ(ツル植物 $)$ & 2検体 $(\mathrm{a}, \mathrm{b})$ & 2検体 $(\mathrm{a}, \mathrm{b})$ \\
\hline 土壌 & 1検体 & 1検体 \\
\hline バックグラウンド & 1検体 & 1検体 \\
\hline イミテーション & & 1検体 \\
\hline
\end{tabular}

をもちい、画面を処理して計測した。ハイネズは3検体、へデラは 2 検体を対象とし、ブランクとして土堙のみを入れた場合と何も入 れない場合について実験を行った。NOxの実験については表面吸着 のみを期待したビニール製の模擬草（イミテーション）を用いた。 植物の場合、測定対象とした部位以外をテドラー(PVF)シートによ 
って被覆することにより、植栽(Planting)、植物部(Plant)、土壤部 (Soil)、それぞれの部位のみへの NOX 収着量を測定した。各部位を 図 9 に示す。測定は、実際に近い環境を得る為に屋外及び安定した 温度、湿度、照度の得やすい屋内において行った。実験期間は表 4 に示すように夏期、中間期、冬期である。植物へのストレスを軽减 するため、1 回の測定時間は 1 時間とした。

\section{$3.2 \mathrm{CO}_{2}$ の濃度減衰実験}

チャンバー内の $\mathrm{CO}_{2}$ 濃度を上昇させるため、 $\mathrm{CO}_{2}$ 高濃度バッグを 作製した。チャンバー内への $\mathrm{CO}_{2}$ ガスの拡散のため、最初の数分間 はミニポンプを用いた。ミニポンプの吸引量は夏期の測定では 6 $\mathrm{l} / \mathrm{min}$ 、中間期、冬期の実験では $5.2 \mathrm{l} / \mathrm{min}$ であった。チャンバー内 濃度を大気環境レベルで考えられ得る範囲の高濃度に上昇させ、そ の後植物等の収着 (吸着十吸収)・吸収などにより実験開始から 60 分まで濃度を減少させ、チャンバー内污染物質濃度の経時変化から 植物による埩化能力を検討した。 $\mathrm{CO}_{2}$ 高濃度バッグは、 $\mathrm{CO}_{2}$ 濃度を $1500 \mathrm{ppm}$ にに調整して用いた。濃度減衰時には $\mathrm{CO}_{2}$ 浄化能力実験で は外気を導入した。

\section{3. $3 \mathrm{NO}_{\mathrm{x}}$ の濃度減衰実験}

大気 NO、構成成分の中でも、NOは植物に吸収されにくいため、 植物に吸収される $\mathrm{NO} \times$ 窒素の大部分は $\mathrm{NO}_{2}$ に由来すると考えられ

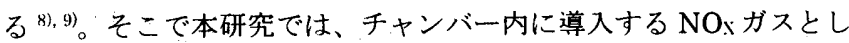
て濃度 $5 \mathrm{ppm}$ 程度の $\mathrm{NO}_{2}$ 標準ガスを使用した。

測定手順としては、 $\mathrm{CO}_{2}$ 濃度減衰実験と同じ方法でチャンバー内 に試験体植物を挿入した後、NO2 標準ガスを毎分 1 亿でチャンバー 内に約 2 分間䆃入し、チャンバー内 NOx濃度を約 $100 \mathrm{ppb}$ 程度ま で上昇させた。始めの濃度上昇時におけるミニポンプの吸引量は夏 期、中間期、冬期共に $4.2 \mathrm{l} / \mathrm{min}$ であった。 NOx濃度の上昇が停止 した時点より、その濃度変化を約 60 分にわたって測定した。NO、 濃度の測定中にチャンバー内に間隙から外気が流入する可能性があ る。そのため、チャ゙ンバー内にゼロガスユニットから NOx 濃度 $0 \mathrm{ppb}$ のゼロガスをポンブによって毎分約 4 l送り込み、常にチャンバー内 を正圧とし、外気のチャンバー内への流入を防止した。NOx濃度の 測定終了後に、冷却システムにおいて捕集された凝縮水量を測定す ると共に、凝縮水中の亜硝酸イオン $\left(\mathrm{NO}_{2}-\right)^{-}$濃度をイオンクロマトグ ラフにより分析した。

\section{4. 濃度減衰実験による $\mathrm{CO}_{2}$ 及び NOx 除去量の評価}

\section{4. $1 \mathrm{CO}_{2}$ 浄化能力の評価方法}

図 10 に $\mathrm{CO}_{2}$ 净化能力の評価方法を示寸。実験開始後ピーク濃度 以降の 15 分から 60 分までのチャンバー内濃度曲線を用いた。植物 が吸収する $\mathrm{CO}_{2}$ 量: $U\left[\mathrm{mg} / \mathrm{min} / \mathrm{m}^{2}\right]$ は周辺濃度(チャンバー内濃度: $C$ ) に比例すると仮定して $U=k \mathrm{cos} \cdot \mathrm{C}$ とし、(7)式より $\mathrm{CO}_{2}$ 吸収フラッ クス: $k c o 2\left[\mathrm{mg} / \mathrm{m}^{2} \mathrm{~min}\right]$ を $\mathrm{CO}_{2}$ 浄化能力の指標とした。葉面積は各 期間にデジタルカメラで撮影した画面を処理して計測した。

$$
\underset{\text { フラックス: }}{\mathrm{CO}_{2} \text { 吸収 }} \quad k_{t^{\prime O 2}}=\frac{C o \cdot q \cdot \Delta t-C(t) \cdot q \cdot \Delta t-V:\{C(t)-C(t+\Delta t)\}}{C(t) \cdot S \cdot \Delta t}
$$

\section{4. $2 \mathrm{NO}_{\mathrm{x}}$ 浄化能力の評価方法}

NOx浄化能力の評価方法を図 11 に示す。まずチャンバー内での NOx の吸脱着や凝縮水への NOxの溶解をゼロと仮定した場合の NOx 濃 度の理論値を求め、 $t=60$ 分時点での理論值と、実験により得られた

\begin{tabular}{c|c} 
表 4 測定期間 & \\
\hline \multirow{2}{*}{ 夏期 } & $2000 / 7 / 13 \sim 7 / 18$ \\
\cline { 2 - 2 } & $1999 / 8 / 24 \sim 9 / 10$ \\
\hline \multirow{2}{*}{ 中間期 } & $2000 / 4 / 3 \sim 4 / 6$ \\
\cline { 2 - 2 } & $1999 / 10 / 4 \sim 10 / 26$ \\
\hline \multirow{2}{*}{ 冬期 } & $2000 / 10 / 24 \sim 10 / 26$ \\
\cline { 2 - 2 } & $1999 / 12 / 17 \sim 12 / 27$ \\
\hline
\end{tabular}

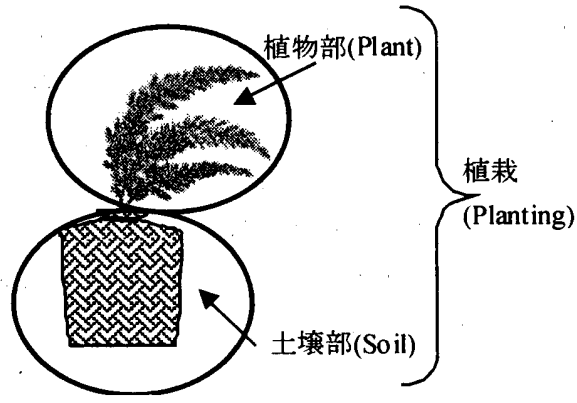

図 9 測定対象部位

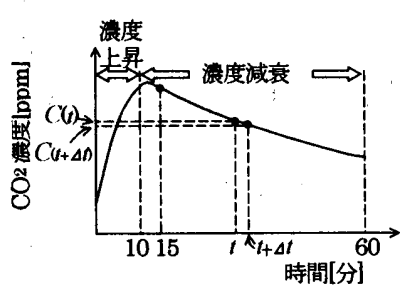

図 $10 \mathrm{CO} 2$ 濃度減衰実験

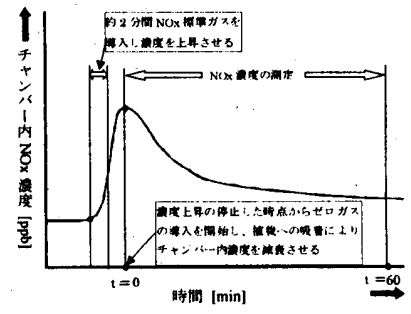

図 11 NOx 浱度减衰実験
NO 濃度の差を NOx減少濃度とした。理論値は(8)式より(9)式を用 いた。次に、冷却系に捕集された凝縮水量と $\mathrm{NO}_{2}-、 \mathrm{NO}_{3}$-イオン濃 度より、凝縮水中に溶け込んだ NOx 量を求めた。大気中、凝縮水中 共に NOx 中の $\mathrm{N}$ のみを換算し、 $\mathrm{N}$ 換算値を NOx 吸着等の指標とし た。

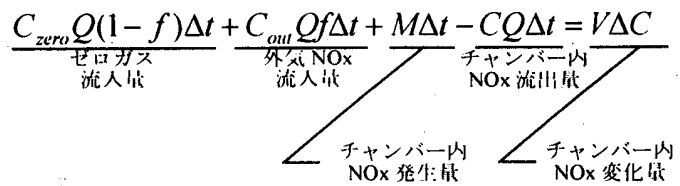

$$
\begin{aligned}
& { }_{c a l} C_{(t+\Delta)}=C_{(t)} e^{\frac{-Q \Delta t}{V}}+\left(1-e^{\frac{-Q \Delta}{V}}\right)\left\{C_{z e r o}(1-f)+C_{o u t} f+\frac{M}{Q}\right\}
\end{aligned}
$$

なお、計算式はチャンバー内部の物質収支に基づくものである。 測定結果よりチャンバー内濃度の微少時間(1 分間)における理論上 の濃度減衰量(計算値) と実測值理論上の濃度減衰量(計算値)と実測 值の濃度减衰量の差を求めることによって、単位時間当りの NOx 収着量 $[\mu \mathrm{g} / \mathrm{min}]$ 及び $\mathrm{NO}$ 収着フラックス $\left[\mu \mathrm{g} / \mathrm{m}^{2} \mathrm{~min}\right]$ を求め、その 值を凝縮水中への NON 溶解量を考慮しない植物による NOx除去量 とした。ただし、実験開始直後の 2 分間はチャンバー内濃度が不安 定となるため、検討対象から外すこととした。その算出式を表 5 に 示す。凝縮水中への NOx 溶解量を考虑した測定毎の植物による NON 除去能力は、測定時間内の単位時間当り NOx減少量の積算值から凝 縮水中への溶解量を減じた值とした。 


\section{5. $\mathrm{NO}_{\mathrm{x}}$ 除去効果における吸収と吸着の影響}

\section{5. $1 \mathrm{CO}_{2}$ 吸収フラックスと $\mathrm{NO}_{x}$ 収着フラックスの相関式}

NO の濃度減衰実験時、チャンバー内に NOx濃度 $0 \mathrm{ppb}$ のゼロ ガスを送り込んだが、チャンバー内の $\mathrm{CO}_{2}$ 濃度の変化を見るため、 外気を導入した濃度減衰実験を行った。その結果に基づいて $\mathrm{CO}_{2}$ 吸 収フラックスと NOx 収着フラックスの比較を行い、NOx 除去効果 における吸収と吸着の影響を評価した。

$\mathrm{NO} \times$ 収着フラックス及び $\mathrm{CO}_{2}$ 吸収フラックスを求める式を式(11)、 (12)に示す。

$u=k \operatorname{co} 2 \cdot C$ と仮定すると、

$k_{N() x}=\frac{u_{N(x)}}{C_{(t)}}=\frac{U_{N O x}}{C_{(t)} S \Delta t}$

$k_{(O) 2}=\frac{C_{(o u t} q \Delta t-C_{(1)} q \Delta t-V\left(C_{t+\Delta t)}-C_{(t)}\right)}{C_{(t)} S \Delta t}$

既往の研究( ににおいて、植物の NOX 吸収フラックス(植物学上では葉 面搪散コンダクタンス)と $\mathrm{CO}_{2}$ 吸収フラックスの関係は式(13)、(14) に示されるように一定であるとされている。

$\frac{u_{N()_{x}}}{u_{C O 2}}=\frac{k_{N O x}}{k_{C O 2}} \frac{C_{N O x}}{C_{C O 2}} \quad$ (13) $\quad \frac{k_{N O x}}{k_{C O 2}}=($ 一定 $)$

これを参考として、実測値における $\mathrm{NO}$ 収着(吸収・吸着) フラ ックスと $\mathrm{CO}_{2}$ 吸収フラックスとの比較を行うことにより、植物の NOx浄化能力における NOx吸収の影響を評価した。結果を図 12 に 示寸。植物部の NOx収着において NOx 吸収の影響が支配的であれ ば、NOx 収着フラックスと $\mathrm{CO}_{2}$ 吸収フラックスとの間には相関が見 られるはずであるが、結果において両者の間に明確な相関関係は見 引れはい。 $\mathrm{CO}_{2}$ 吸収フラックスがマイナスに転じている時にも NO、 収着フラックスはブラスになっている。このことは、植栽による NO : 浄化能力には植物内への吸収だけでなく、表面への吸着等他の 要因が大きく奇与していることを示している。

\section{$5.2 \mathrm{NO}$ x 暴露履歴の影響}

植物部への NOxの暴露履歴によって、植栽への NOx 収着フラッ クスに生じる差異について検討した。純水により 60 分間洗浄を行 い表面に吸着した NOxを洗い流した試験体と、同様に洗浄した後に $\mathrm{NO} 2$ 標準ガス $(5 \mathrm{ppm})$ にそれぞれ 20 分間、40 分間暴露した試験体を 用いて濃度減衰実験を行い、その際の NON 収着フラックスの值を比 較した。結果を図 13 に示す。暴露時間の違いによる収着フラック スけ值には差が生じて抢らず、暴露時間に比例した明確な増減も表 れていない。本実験で行ったレベルの NOx 暴露時間では、NOx 収 着フラックスの值には影響を及ぼさないことが示された。

濃度減衰実験終了直後の試験体において、葉への NOx の吸着量を 測定した。実験終了直後に、葉の一部を純水 $50 \mathrm{ml}$ に 5 分間浸すこ とで葉についた NOxを純水中に溶解させ、その純水中の $\mathrm{NO}_{2}$-イオ ンの量をイオンクロマトグラフにより測定した。結果を表 6 に示す。 40 分間暴露した葉を浸した純水から $\mathrm{NO}_{2}$-イオンが検出されたこと より、菄表面にNOxが吸着していることが示された。

\section{3 植栽の乾嬠と湿潤の影響}

植栽に 3 日間水を与えない状態を乾燥時、純水に浸した直後の状
表 5 污染物質浄化能力の評価法

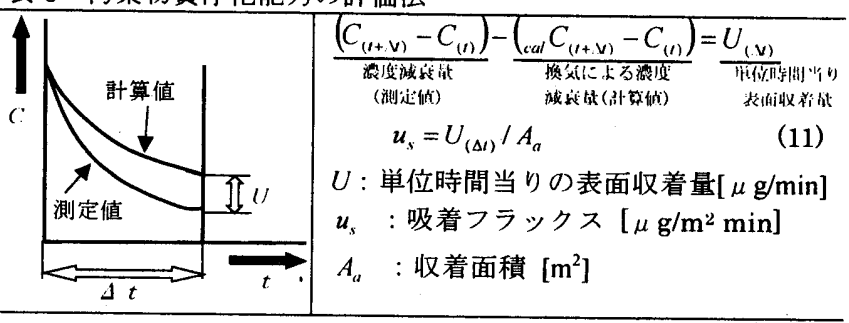

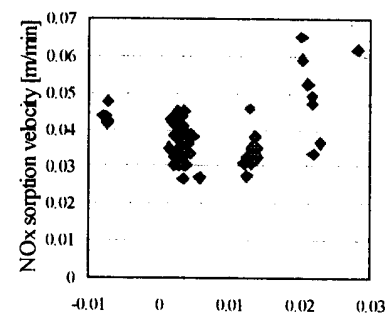

$\mathrm{CO}_{2}$ absorption velocity $[\mathrm{m} / \mathrm{min}]$

図 $12 \mathrm{NO}$ 収着フラックスと $\mathrm{CO}_{2}$ 吸収フラックスの関倸

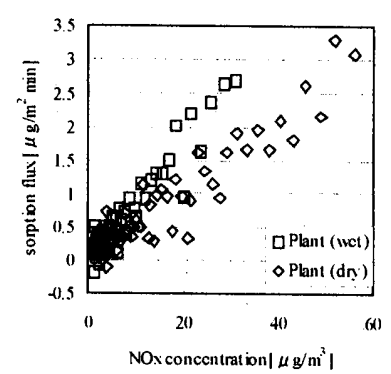

(a) 植物部

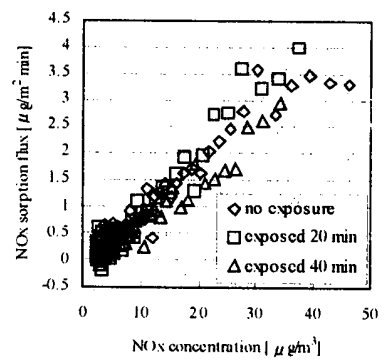

図13 NON暴露履歷と NON 収着フラックスの関係

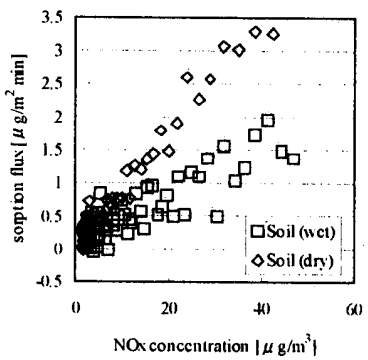

(b) 土壤部
図 14 乾燥時と湿潤時の NOx 収着フラックス

表 6 葉を洗浄した純水の分析結果

\begin{tabular}{c|c|c|c}
\hline 曝露時間 & \multicolumn{2}{|c|}{ 曝露なし } & \multicolumn{2}{|c|}{ 曝露 20 分 } & 曝露 40 分 \\
\hline $\mathrm{NO}_{2}{ }^{-}[\mathrm{mg} / \mathrm{l}]$ & Not found & Not found & 0.0707 \\
\hline
\end{tabular}

態を湿潤時としてそれぞれ濃度減衰実験を行い、NOx 収着フラック スの比較を行った。結果を図 14 に示す。植物部においては乾燥時 よりも湿潤時の值が高くなっている。これは、表面に吸着している 水への NONの溶解が要因として考えられる。土壌部においては逆に 乾燥状態の方が湿潤状態よりも収着フラックスの值が約 2 倍程度高 くなっている。

\section{6. 測定結果}

実験開始後 10 分間は高濃度バッグを接続してチャンバー内 $\mathrm{CO}_{2}$ 濃度を上昇させ、その後外気を導入した。各期間の実験結果を図 15 に示す。夏期および中間期の実験ではチャンバーの気密性が低く、 また中間期では高濃度バッグの濃度が低いために中間期の濃度は全 体的に低くなった。各実験においても外気濃度、ピーク濃度は異な るが、実験開始より 15 分以降の外気導入時には植物が存在してい るほうが $\mathrm{CO}_{2}$ 濃度の減衰が激しく、特に夏期にはその傾向が顕著で ある。NON $の$ 場合、実験開始後 6 分間は高濃度バッグを接続してチ ヤンバー内 NON 濃度を上昇させ、その後ゼロガスバッグよりゼロガ 

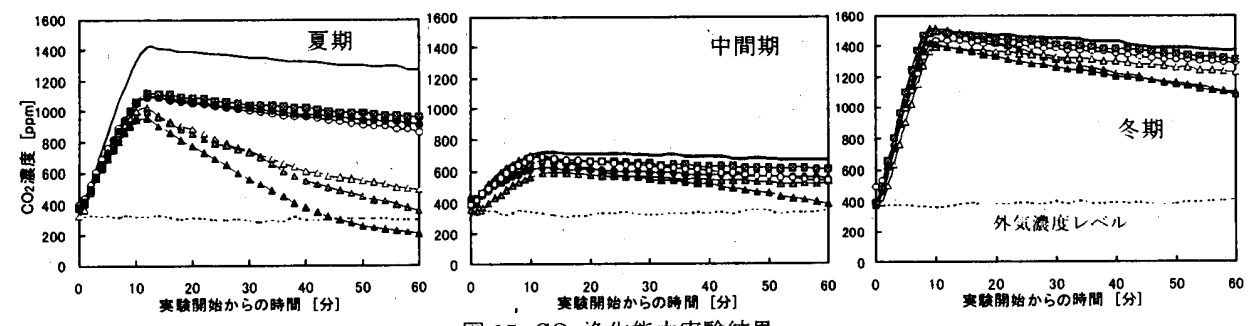

図 $15 \mathrm{CO} 2$ 浄化能力実験結果
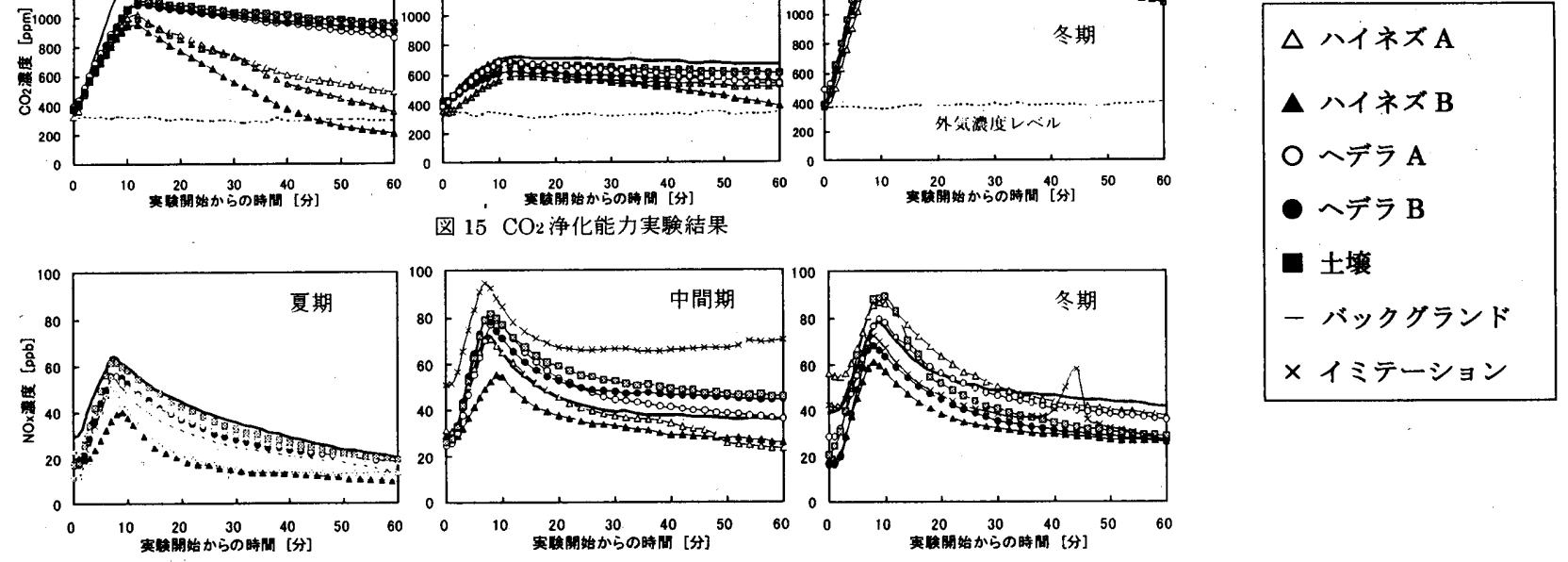

図 16 NOx 鿇化能力実呀結果

スを導入した。NOx濃度測定の実験結果を図 16 に示す。夏期はチ ヤンバーの気密性が低いため全体的に濃度が低く、初期濃度にばら つきがある。平均すると八イネズやへデラの存在する場合のほうが 「バックグラウンド」「土壌」の場合に比べて NOx 濃度の隇少が大 きい。従って、植物は大気中の NOx濃度の減少に寄与していると考 えられる。

各季節別のハイネズの平均 $\mathrm{CO}_{2}$ 吸収量及び NOx 収着量を表 7 に 示す。夏期、中間期、冬期の全ての実験について $\mathrm{CO}_{2}$ は、60 分間の 平均吸収量を示した。NOx は $\mathrm{t}=60$ 時点での理論值と実験により得 られたチャンバー内 NOx 濃度差を求め、後の凝縮水考慮の為に NOx 中の $\mathrm{N}$ 量だけに着目して $\mathrm{N}$ 換算値を求めた。

\section{7. おわりに}

本研究では植物による NON の鿇化能力実験結果をもとに、NOx 濃度を植物の有無により比較することで污染物質除去効果の検証を 行った。以下に得られた結果を述べる。

（1）濃度減衰実験による植物の NO 除去効果を検証するにあたり、 測定システムを作製した。

（2）濃度減衰実験により植物は空気中の $\mathrm{CO}_{2}$ 及び $\mathrm{NO}_{x}$ 濃度の減少 に寄与していることが確認された。

（3）システムの NOx吸脱着特性を評価するためチャンバー内 NOx 吸脱着フラックスを求めた。また、ハイネズの NOx収着フラッ クスを求め、 $\mathrm{CO}_{2}$ 吸収フラックスとの関倸を明らかにした。

（4）植物によるNO、除去には、植物内への吸収だけではなく吸着作 用も寄与していることを示した。

記号

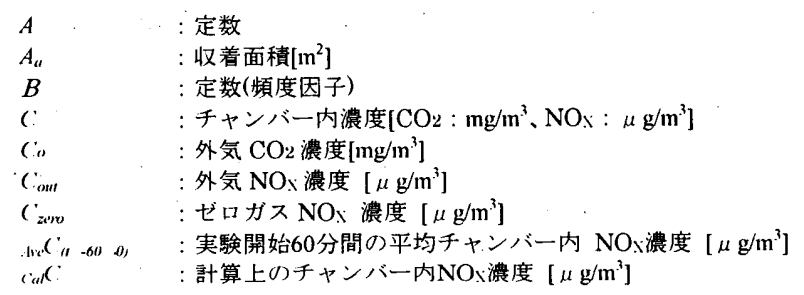

表 7 ハイネズの $\mathrm{CO}_{2}$ 吸収量及び $\mathrm{NOx}$ 収着量

\begin{tabular}{|c|c|c|c|}
\hline 項 & 夏期 & 中間期 & 冬期 \\
\hline 葉面積 $\left[\mathrm{cm}^{2}\right]$ & 800 & 763 & 796 \\
\hline $\mathrm{CO}_{2}$ 吸収量 $\left[\mathrm{mg} / \mathrm{min} / \mathrm{m}^{2}\right]$ & 46.69 & 13.89 & 4.87 \\
\hline NOx収着量 $[\mu \mathrm{gN}]$ & 4.42 & 2.94 & 3.25 \\
\hline
\end{tabular}

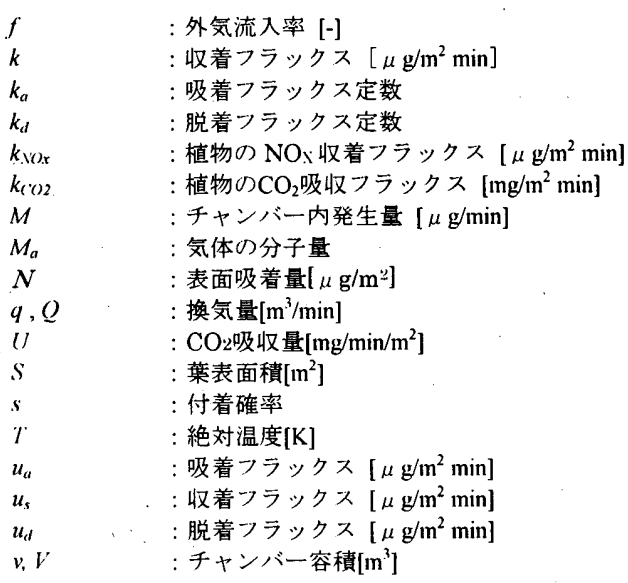

\section{参考文献}

1) 梅干野晃：都市の緑とアメニティー都市の緑と環境物理，日本建築学会 環境工学部門研究協議会資料, pp. 1 26, 1993

2）H. ビーヴァース・赤沢克：植物の代謝生理，岩波書店，pp. 175 177, 1986 3）金子和己・島田幸司・高見勝重：土壤を用いた大気浄化システムの実施例 と今後の展開，環境資源対策，pp. $542 \sim 550,1999$

4) 被害補償予防協会: 大気浄化植樹マニ=ュアル, 公害健康被害補偵予防協会, 1995

5）小川和雄：埼玉県内緑地に上る大気浄化量 0 推定，水，30３4，1994

6) 戸㙇績、三宅博：緑地の待機净化機能, 大気污染学会誌, 26(4), A71 A80, 1991

7）熊谷寛夫・富永五郎ほか：真空の物理と応用，裳華房，1992

8) Hill, A. C.: Vegetation: A sink for atmospheric pollutants, J. Air Pollut. Contr. Assoc., pp.21, 341-346, 1971

9）岡野邦夫，古川昭雄：植物の NO 2 吸収量を指標とした大気 NO x 污染度 評価, 大気污染学全誌, Vol. 25, No.6, pp.371-377, 1990

10) 日本化学会: 季刊化学総説, No.30, 学会出版センター, 1996

11) 戸塚績：緑化に上る都市の空気浄化, 空気調和·衛生工学, 第 68 巻, 第 11

号, 1994

12）野内勇：大気環境変化々植物の反応，養賢堂，2001.6

13) 長谷場徽也：植物 $\sigma$ 葉面境界層輸送係数，農業気象，40(1)，63～72, 1984

14) 東京都環境局：東京都環境白書 2000,2000 